\title{
The role of B- and T-cell immunity in toltrazuril-treated C57BL/6 WT, $\mu M T$ and nude mice experimentally infected with Neospora caninum
}

Received: 12 January 2004 / Accepted: 29 January 2004 / Published online: 5 May 2004

(C) Springer-Verlag 2004

\begin{abstract}
Neospora caninum is a protozoan parasite predominantly known for causing abortion in cattle and neuromuscular disease in dogs. So far, no efficient metaphylactic chemotherapy has been developed. In preliminary studies, toltrazuril had been successfully used against experimental neosporosis in mice and calves. In the present study, we used immunocompetent and immunodeficient mouse strains to address the role of immunity in supporting the chemotherapy of experimental $N$. caninum infection. WT, $\mu \mathrm{MT}$ and athymic nude mice were intraperitoneally inoculated with $1 \times 10^{6}$ Nc-1 tachyzoites. The drug was administered in the drinking water for 6 consecutive days so as to obtain a daily dose of approximately $20 \mathrm{mg}$ toltrazuril $/ \mathrm{kg}$ body weight. The course of infection was monitored by clinical, histological and immunohistochemical means, as well as by the search for parasite DNA using PCRanalyses of various organs. In immunocompetent WT mice, treatment proved to be of high efficacy by abrogation of any lesion formation or PCR-positivity in medicated $\mathrm{C} 57 \mathrm{BL} / 6$ mice and a significant reduction of lesion formation or PCR-positivity in BALB/c animals. Similarly, treated $\mu \mathrm{MT}$ mice exhibited a significant reduction in cerebral lesion formation as well as in parasite DNA detectability by PCR when compared to untreated animals. Athymic nude mice, however, did not respond to treatment in that only a delay of the parasite dissemination was achieved, and nude mice still showed the neosporosis disease symptoms, although later than untreated animals. We conclude that treatment with toltrazuril appears to act parasitostatically rather than parasitocidically. This is supported by the fact that: (1) although the lack of B-cells did not impair the effect of
\end{abstract}

P. Ammann · I. Breyer · M. Esposito $\cdot$ N. Müller

B. Gottstein ( $\square)$

Institute of Parasitology, University of Berne, Länggass-Strasse 122, 3012 Berne, Switzerland

E-mail: bruno.gottstein@ipa.unibe.ch

A. Waldvogel

Institute of Animal Pathology, University of Berne, Länggasss-Strasse 122, 3012 Berne, Switzerland toltrazuril, (2) the lack of T-cells did not allow for a full efficacy of treatment. Therefore, chemotherapy with toltrazuril against experimental infections with $N$. caninum requires the support of T-cell immunity in order to be successful.

\section{Introduction}

The main problems associated with Neospora caninum infections are abortion in cattle and a severe neuromuscular disease in dogs (Dubey 2003). Most Neosporainduced abortions occur between 5 and 6 months of gestation. In utero infected calves may also be born alive, with or without clinical symptoms, but remaining persistently infected. The outcome of neosporosis during gestation is dependent on the time of infection or recrudescence, among other features (Innes et al. 2000). Vertical transmission is an important way of maintaining the infection in a herd (Anderson et al. 1997; Schares et al. 1998; Davison et al. 1999) and may occur several times in one particular cow. The abortion risk in seropositive cows is four times higher than in seronegative cows (Sager et al. 2001).

The need for the development of effective pro- or metaphylactic measures against bovine neosporosis has been widely discussed (Liddell et al. 1999; Greif et al. 2001; Gottstein et al. 2001; Innes et al. 2002; Kritzner et al. 2002). Effective vaccines to protect cattle from abortion on vertical parasite transmission are currently not available (Andrianarivo et al. 2000; Innes et al. 2002). So far, quite a wide range of chemotherapeutic agents has been tested against $N$. caninum. Some pharmacologically active compounds are known to kill the parasite in cell culture-based assays (Lindsay et al. 1994; Dubey 2003). Recently, artemisinin and depudecin were also found to have an anti-parasitic activity against $N$. caninum in vitro (Kim et al. 2002; Kwon et al. 2003). Oral drug treatment of mice with sulfadiazine and amprolium was rather ineffective (Lindsay and Dubey 
1990b). So far, the efficacy of toltrazuril and ponazuril (triazinone derivatives) against neosporosis has been assessed in experimentally infected immunocompetent mice and calves (Gottstein et al. 2001; Kritzner et al. 2002). Toltrazuril was suggested to act at least against tachyzoites, and appeared not to abrogate the development of immunity (Greif 2000).

Experimentally, mice represent a valuable model for the study of certain aspects of $N$. caninum infection. $N$. caninum predominantly affects the central nervous system in mice (Lindsay et al. 1995; Yamage et al. 1996). In acute murine neosporosis further clinical signs are seen, such as pneumonia, myositis, encephalitis, ganglioradiculoneuritis and pancreatitis (Lindsay and Dubey 1990a).

Various types of immunological deficiencies have been used to assess the importance of specific components of the immune system. Interferon- $\gamma$-knockout mice developed acute and lethal neosporosis within 2 weeks (Ritter et al. 2002). Nude mice are very susceptible to $N$. caninum and develop acute neosporosis (Yamage et al. 1996; Shibahara et al. 1999). B-celldeficient C57BL/6 $(\mu \mathrm{MT})$ mice have also been proven to be highly susceptible to neosporosis (Eperon et al. 1999).

The aim of the present study was to find out whether a humoral or cellular immune response is required to support chemotherapy with toltrazuril. We addressed the question experimentally using B-cell-deficient ( $\mu \mathrm{MT})$ mice and the corresponding C57BL/6 wild-type (WT) controls, as well as athymic nude $\left(\mathrm{nu}^{-} / \mathrm{nu}^{-}\right)$mice and the corresponding BALB/c WT controls.

\section{Materials and methods}

Experimental design and animals

Chemotherapy with toltrazuril against murine neosporosis was carried out after Gottstein et al. (2001). Tracking efficacy was predominantly based on: (1) the detection of parasite DNA in the brain, and (2) the demonstration of parasite induced brain lesions - as detected by histopathology and immunohistochemistry. Based on our earlier experiments with mice, drug application by drinking water was chosen (Gottstein et al. 2001). For a daily uptake of approximately $20 \mathrm{mg}$ toltrazuril/kg body weight, $62.5 \mathrm{mg}$ toltrazuril $/ 100 \mathrm{ml}$ water was given. The average water consumption was estimated as $0.6 \mathrm{ml} /$ day for each mouse, so approximately $0.42 \mathrm{mg}$ toltrazuril was ingested daily. The weight of the mice at the beginning of the experiments ranged from 20 to $25 \mathrm{~g}$. Medication was started at the same time as infection and was maintained for 6 days consecutively. For experimental infection, all mice were inoculated intraperitoneally (i.p.) with $10^{6} \mathrm{Nc}-1$ tachyzoites, suspended in $200 \mu \mathrm{l}$ PBS. Infection was performed at a relatively low dose (compared to Gottstein et al. 2001), as we anticipated the immunodeficient mice to be much more susceptible to neosporosis (assessed by preliminary titration experiments, data not shown). All mice were 8-week-old females. Housing and feeding were according to the Swiss regulations on animal experimentation.

The animals used for experimental infections included four different mouse strains: 24 C57BL/6 WT mice (Harlan, Horst, The Netherlands), 19 B-cell-deficient $\mu \mathrm{MT}$ mice (breeding couple provided by Dr. A. Macpherson, Institute of Experimental Immunology, University of Zurich, Switzerland), 24 BALB/c mice and 18 athymic $(\mathrm{nu}+/ \mathrm{nu}+)$ BALB/c mice (both from Harlan).

For each mouse strain $(\mathrm{C} 57 \mathrm{BL} / 6$ and $\mathrm{BALB} / \mathrm{c})$, a total of 24 WT mice were used, eight of which were infected with $10^{6} \mathrm{Nc}-1$ tachyzoites and subjected to toltrazuril medication. Another eight mice were simultaneously infected but kept without medication (see Table 1). Four other mice served as a negative control (no infection, no medication) and four were only treated.

In a first attempt, $12 \mathrm{BALB} / \mathrm{c}$ athymic nude mice were infected intraperitoneally with $10^{6} \mathrm{Nc}-1$ tachyzoites. Six of these were treated with toltrazuril as described before while six served as controls, three with therapy (and no infection) and three without any

Table 1 Presence of Neosporum caninum, assessed by PCR, is shown for selected organs in treated versus untreated WT mice (numbers of PCR-positive organs per total organs are shown). Necropsy occurred at day 29 p.i.

\begin{tabular}{|c|c|c|c|c|c|c|c|}
\hline & & PCR brain & PCR heart & PCR lung & PCR liver & PCR kidney & PCR spleen \\
\hline \multirow[t]{3}{*}{ C57BL/6 WT mice } & Infection and therapy & $0 / 8$ & $0 / 8$ & $0 / 8$ & $0 / 8$ & $0 / 8$ & $0 / 8$ \\
\hline & Infection, no therapy & $7 / 8$ & $0 / 8$ & $0 / 8$ & $0 / 8$ & $0 / 8$ & $0 / 8$ \\
\hline & $\begin{array}{l}\text { Controls, not infected, } \\
\text { no therapy }\end{array}$ & $0 / 4$ & $0 / 4$ & $0 / 4$ & $0 / 4$ & $0 / 4$ & $0 / 4$ \\
\hline \multirow[t]{2}{*}{ BALB/C WT mice } & Infection and therapy & $2 / 8$ & $0 / 8$ & $0 / 8$ & $0 / 8$ & $0 / 8$ & $0 / 8$ \\
\hline & $\begin{array}{l}\text { Controls, not infected, } \\
\text { no therapy }\end{array}$ & $0 / 4$ & $0 / 4$ & $0 / 4$ & $0 / 4$ & $0 / 4$ & $0 / 4$ \\
\hline
\end{tabular}


intervention. An additional experiment, including eight nude mice, was carried out in order to monitor the treatment over a longer period, planned for 29 days. An additional experiment, including eight nude mice, was carried out in order to monitor the treatment over a longer period, planned for 29 days.

All WT and $\mu$ MT mice were killed on day 29 postinfection (p.i.). Athymic nude mice were killed either when the symptoms occurred (according to animal welfare guidelines) or on day 29 p.i. Death was induced by $\mathrm{CO}_{2}$ inhalation. Blood was taken by cardiac puncture for serum isolation. One brain hemisphere and pieces of heart, lung, liver, kidney and spleen were collected and stored at $-20^{\circ} \mathrm{C}$ until PCR analysis was performed. The other brain hemisphere was fixed in PBS-buffered $4 \%$ paraformaldehyde, and after paraffin-embedding sections were stained with haematoxylin-eosin, or used for immunohistochemistry.

\section{Parasites}

$N$. caninum tachyzoites from the Nc-1 isolate (Dubey et al. 1988) were maintained in Vero cells. The Vero cells were cultivated in RPMI-1640 medium (Gibco, Basel, Switzerland) supplemented with $7 \%$ fetal calf serum (FCS), $2 \mathrm{mM}$ glutamine, 50 units penicillin $/ \mathrm{ml}$, and $50 \mu \mathrm{g}$ streptomycin $/ \mathrm{ml}$ at $37^{\circ} \mathrm{C}$ with $5 \% \mathrm{CO}_{2}$ in tissue culture flasks. The tachyzoites were harvested from the infected Vero cells by trypsination followed by repeated passage through a 25 -gauge needle. Host cell debris was removed from the parasites by separation on SephadexG25 columns as described previously (Hemphill et al. 1996). The tachyzoites were counted using a Neubauer chamber and diluted in PBS until $200 \mu$ contained the above mentioned number of parasites.

\section{DNA isolation and PCR}

DNA was extracted from each sample using the DNeasy kit (Quiagen, Basel, Switzerland) according to the manufacturer's recommendations. Tissues were digested overnight, and DNA eluted followed by denaturation at $95^{\circ} \mathrm{C}$. PCR was done as previously described (Müller et al. 1996) with $N$. caninum-specific primers Np21plus (5' CCCAGTGCGTCCAATCCTGTAAC $3^{\prime}$ ) and Np6 plus (5' CTCGCCAGTCAACCTACGTCTTCT $3^{\prime}$ ) in a thermal cycler (Gene Amp PCR System model 9700) for 40 cycles $\left(94^{\circ}, 1 \mathrm{~min} ; 63^{\circ} \mathrm{C}, 1 \mathrm{~min} ; 74^{\circ} \mathrm{C}, 2.5 \mathrm{~min}\right)$. After the last cycle, a primer extension was continued for $15 \mathrm{~min}$ at $72^{\circ} \mathrm{C}$. For each sample, the mixture with a total volume of $25 \mu \mathrm{l}$ contained $17.625 \mu \mathrm{l}$ of water, $2.5 \mu \mathrm{l}$ of $10 \times$ Gene Amp PCR buffer, $2.5 \mu \mathrm{l}$ of a nucleotide mixture with $0.2 \mathrm{mM}$ each dATP, dGTP and $\mathrm{dCTP}$, and $0.4 \mathrm{mM}$ dUTP, $0.5 \mu \mathrm{l}$ containing $20 \mathrm{pmol}$ each of Np21plus and Np6plus, $0.25 \mu 1$ uracyl DNA glycosylase (UDG) (Gibco) and $0.125 \mu \mathrm{l}$ AmpliTaq DNA polymerase (Perkin Elmer Cetus, Rotkreuz,
Switzerland). Pipetting the mixtures and thermal amplifications were done in separate rooms to avoid contamination. To prevent carry-over contamination from previous reactions, the samples were incubated with UDG. Prior to PCR, the reaction mixture was initially incubated for $10 \mathrm{~min}$ at $20^{\circ} \mathrm{C}$. The UDG was inactivated by incubation at $95^{\circ} \mathrm{C}$ for $2 \mathrm{~min}$. For each sample, a parallel inhibition control was performed to exclude putative false-negative results.

\section{Serology}

Mouse sera were analyzed for the presence of antibodies against Nc-1 antigen by enzyme-linked immunosorbent assay (ELISA) using the same somatic antigen (SA antigen) as previously described (Gottstein et al. 2001). An alkaline-phosphatase conjugated goat anti-mouse $\operatorname{IgG}(\mathrm{Fc})$ was used as second antibody. Absorbance was read at $403 \mathrm{~nm}$ (reference filter $630 \mathrm{~nm}$ ) using a Dynatech MR 7000 ELISA reader and the corresponding Dynatech Biocalc software (Dynatech, Embrach, Switzerland). Three standard deviations were added to the mean of ten negative mouse controls of the respective genetic background (no infection, no treatment). This value served as the cut-off to discriminate between negative and positive reactions.

\section{Histopathology and immunohistochemistry}

Tissue samples were fixed in 4\% neutrally buffered paraformaldehyde and embedded in paraffin. Hematoxylin and eosin (HE) stained sections were analyzed by light microscopy (LM) with the cerebellum, pons, hipocampus, thalamus, basal ganglia and the cerebral hemisphere being searched for lesions. These were assigned to one of four grades: (-) without significant lesion, $(+)$ few foci of inflammatory cells and small perivascular cuffs, $(++)$ moderate inflammation and necrotic foci can occur, $(+++)$ severe inflammation with extensive necrosis.

For immunohistochemistry, paraffin sections of brain tissue were deparaffinized in xylene and rehydrated in graded methanol $(100 \%, 90 \%, 70 \%, 50 \%, 30 \%)$ for $5 \mathrm{~min}$ at each concentration. The rehydration was followed by a washing step with distilled water and incubation in PBS. The tissues were predigested with $0.1 \%$ pronase (protease type XXVIII, Nagarse, Sigma) in Tris- $\mathrm{HCl}$ buffer 0.05 for $5 \mathrm{~min}$ at $37^{\circ} \mathrm{C}$. Blocking was done with PBS containing $1.5 \%$ bovine serum albumin (BSA) and $50 \mathrm{mM}$ glycine (blocking buffer) for $2 \mathrm{~h}$ at room temperature in a humid chamber. The sections were washed three times in PBS, each time for $5 \mathrm{~min}$. A polyclonal rabbit-anti- $N$. caninum antibody (Gottstein et al. 2001) was applied as primary antibody at a dilution of 1:250 in a blocking buffer (PBS with 1.5\% BSA) for $1.5 \mathrm{~h}$ at room temperature in a humid chamber. After three washings in PBS of $5 \mathrm{~min}$ each, goat anti-rabbit 
FITC (Sigma) was applied as second antibody at a dilution of 1:100 in blocking buffer (PBS with 1.5\% BSA) for $30 \mathrm{~min}$. The slides were washed again three times in PBS for $5 \mathrm{~min}$. The samples were incubated in the fluorescent dye Hoechst 33258 (1:300 in PBS) for 2 min, rinsed again in PBS and mounted in Fluoroprep (BioMerieux, Geneva, Switzerland). The slides were analyzed on a Leitz Laborlux S fluorescence microscope and the severity of infection was classified as follows: (-) no parasites, $(+)$ less than 20 parasites, $(++)$ 20-200 parasites and $(+++)$ more than 200 parasites per slide.

Sections stained with HE were analyzed by LM (per mouse and brain), and an adjacent section was used for immunohistochemistry.

\section{Chemotherapy}

Medication with toltrazuril (Baycox, Bayer) was given via the drinking water for 6 consecutive days. The normal water was replaced by water containing the drug just after infection. To yield a daily uptake of $20 \mathrm{mg} / \mathrm{kg}$ BW, $62.5 \mathrm{mg}$ toltrazuril $/ 100 \mathrm{ml}$ water was given. The average water consumption was estimated as $0.6 \mathrm{ml} /$ day for each mouse, so that approximately $0.42 \mathrm{mg}$ toltrazuril was ingested daily. The weight of the mice at infection ranged between 20 and $25 \mathrm{~g}$. Optimal administration and dose had been assessed previously (Gottstein et al. 2001).

\section{Results}

\section{Neospora-PCR}

None of the WT mice showed any clinical symptoms until death. Brain, heart, lung, liver, kidney and spleen samples of WT mice were analyzed by PCR (Table 1). Parasite DNA was not detected in any of the organs of the infected and medicated groups of C57BL/6 mice. In the $\mathrm{BALB} / \mathrm{c}$ animals, two out of eight were PCR positive. Conversely, in mice that were infected but not medicated, PCR yielded a positive result in the brains of seven out of eight animals for the C57BL/6-strain and six out of eight for the $\mathrm{BALB} / \mathrm{c}$-strain. In the brainpositive animals, all other organs were free of detectable parasite DNA. All uninfected control mice were completely negative by PCR examination.
Of the $19 \mu \mathrm{MT}$ mice investigated, eight were infected and treated with toltrazuril (Table 2). Eight other mice were infected with the same dose but received no medication. Three mice served as negative controls (no infection, no treatment). One mouse from the untreated group died 26 days after infection. All other mice were killed 29 days after infection. None of the animals showed any clinical symptoms. All individuals from the infected and treated group were completely negative by PCR, as parasite DNA remained undetected in any of the brains or other organs. Conversely, N. caninum DNA was detected in all brains of the infected and untreated mice. One mouse had an additional positive PCR result in the heart and the lungs, four in the lungs and one in the kidneys. All control mice were completely negative by PCR.

The presence of $N$. caninum, assessed by PCR, in selected organs in treated versus untreated athymic nude mice is shown in Table 3. Two untreated BALB/c animals died 14 days after infection. One mouse was ill at this time and died 15 days after infection. The remaining three untreated mice also became sick and were therefore killed. The mice showed clinical signs, including shivering, a bent back, neurological symptoms and apathy. They were thin, and at necropsy no intraperitoneal fat was found. No symptoms were seen in control-treated animals and untouched controls. Five treated mice and five controls were killed on the same day as the untreated mice in order to compare the different groups at the same stage of infection. Of the eight treated mice in the second experimental nude mouse group, three died prematurely on day 26 p.i. and two after 27 days. The remaining three mice were killed 28 days after infection because they were apathic and thin. In the first series of nude mice killed on day 15 p.i., only one out of five infected and treated animals had a positive PCR result, whereas all six infected mice without therapy had detectable parasite DNA in their brains. The parasite was also found in several mice of both groups. The heart was affected in four treated and four untreated mice and the lungs of all infected animals were also infected. The liver and kidneys were less affected in treated than in untreated mice. As expected, all of the six uninfected control mice were negative by PCR analysis. In the second experimental series with nude mice, parasite DNA was detected in seven out of eight mice. Except for one mouse with a negative brain PCR, which nevertheless had detectable DNA in the heart, the parasite was detected in every other organ examined.

Table 2 Presence of $N$. caninum, assessed by PCR, in selected organs in treated versus untreated antibody-deficient $\mu \mathrm{MT}$ mice (numbers of PCR-positive organs per total rgans are shown). Necropsy occurred at day 29 p.i. One mouse died 26 days p.i. in the infection no therapy group, samples from the organs of which were also included

\begin{tabular}{lllllll}
\hline$\mu$ MT mice & PCR brain & PCR heart & PCR lung & PCR liver & PCR kidney & PCR spleen \\
\hline Infection and therapy & $0 / 8$ & $0 / 8$ & $0 / 8$ & $0 / 8$ & $0 / 8$ & $0 / 8$ \\
Infection, no therapy & $8 / 8$ & $1 / 8$ & $5 / 8$ & $0 / 8$ & $1 / 8$ & $0 / 8$ \\
Controls, not infected, & $0 / 8$ & $0 / 8$ & $0 / 8$ & $0 / 8$ & $0 / 8$ & $0 / 8$ \\
\begin{tabular}{l} 
untreated \\
\hline
\end{tabular} & & & & & \\
\hline
\end{tabular}


Table 3 Presence of $N$. caninum, assessed by PCR, in selected organs in treated versus untreated athymic nude mice (numbers of PCR-positive organs per total organs are shown). Necropsy occurred at day 29 p.i. Three mice from the infection and therapy group (day 29) died prematurely on day 26 p.i. and two after 27 days p.i. The remaining three mice were killed 28 days after infection because they showed severe clinical signs of neosporosis. Thus, no nude mouse reached the planed time span of 29 days p.i.

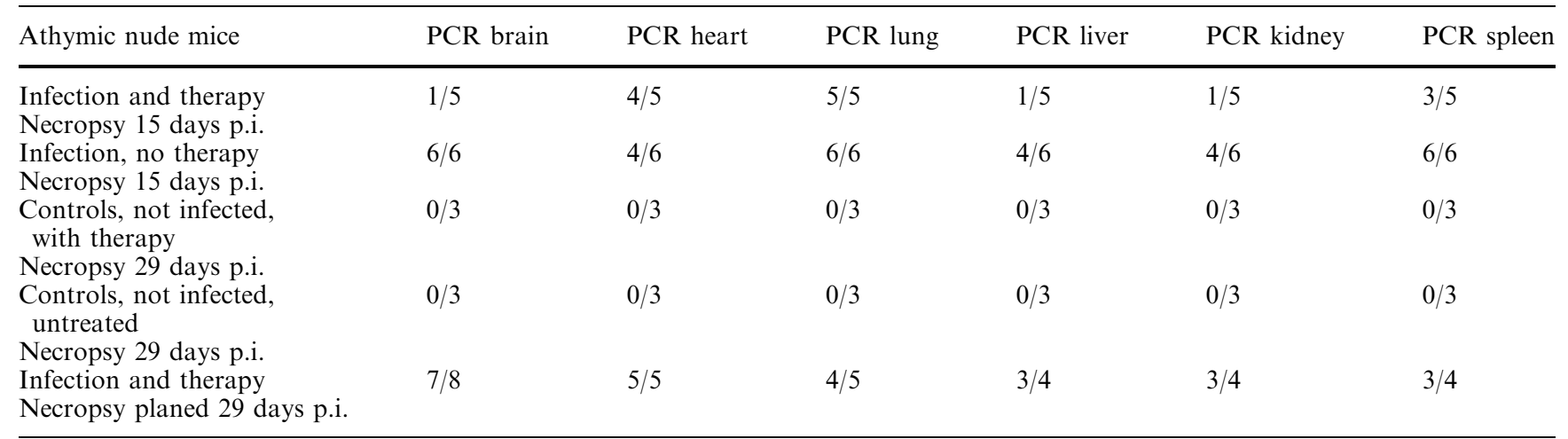

Comparing the treated mice with the untreated mice at 15 days p.i., the infection appeared more widespread in untreated mice than in medicated animals. After 29 days, this effect was abrogated in that the infection appeared more or less identically spread in the whole body of all animals in both mouse groups.

\section{ELISA}

All WT mice (of both strains) inoculated with N. caninum had produced antibodies in response to infection. ELISA results are shown in Fig. 1. The mice that had received toltrazuril treatment developed significantly lower antibody concentrations than the untreated mice. These observations are in line with earlier findings (Gottstein et al. 2001).

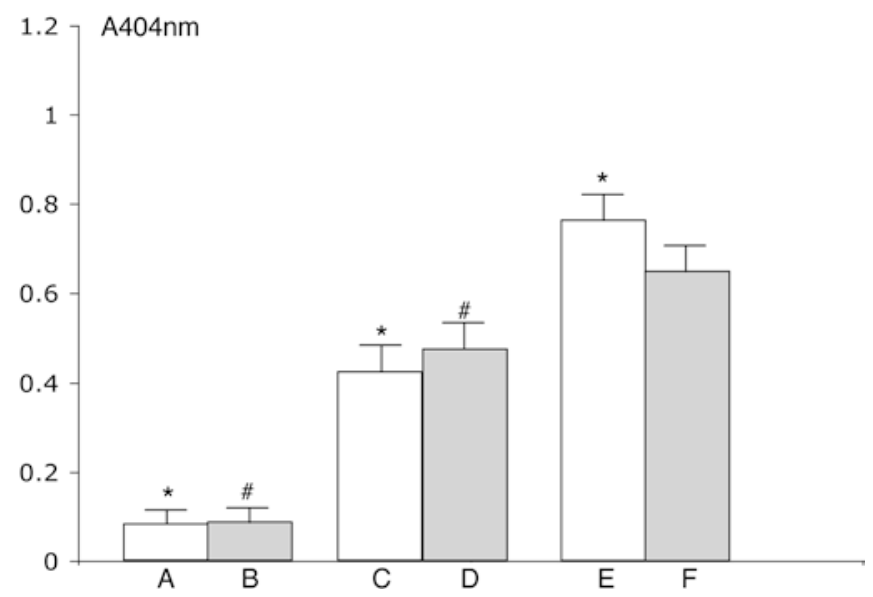

Fig. 1 Mean antibody reactivities $( \pm \mathrm{SE})$ in WT mice determined by ELISA. White bars refer to C57BL/6 and grey bars to BALB/c WT mice. $A$ and $B$ represent uninfected control mice, including both untreated and toltrazuril treated animals. $C$ and $D$ represent infected and toltrazuril-treated mice, $E$ and $F$ infected and untreated animals. * and \# indicate statistically significant differences between the respective groups of the respective strain, at $P \leq 0.05$ (Student's $t$-test). The difference between $D$ and $F$ was not significant $(P=0.27)$ $\mu \mathrm{MT}$ (B-cell-deficient) and nude (T-cell-deficient) mice are incapable of antibody production. As expected, all results of the ELISA were below the cut-off value, thus none of these mice produced any antibody response (data not shown).

\section{Histology}

Three HE-stained coronary sections taken at three different levels from each mouse brain (from all strains) were analyzed by LM. All sections were histologically classified into four grades according to the pathological findings (Figs. 2, 3). For the C57BL/6 WT mice, no lesions or inflammation were visible in any samples from the medicated animals, whereas two of the eight BALB $/ \mathrm{c}$ mice exhibited a few foci of inflammation (Table 4). Conversely, in C57BL/6 WT mice without therapy, foci with slight to moderate inflammation were detected in all brains, and in six of eight $\mathrm{BALB} / \mathrm{c}$ mice necrosis/ inflammation was apparent. As expected, the brains from control mice (medicated and untreated) were free from any signs of inflammation.

Slight lesions were found in three $\mu \mathrm{MT}$ treated mice, including mainly foci with inflammatory cells and perivascular cuffs. The other five mice were within normal limits. In one mouse from the untreated group, slight lesions were found. One mouse showed moderate lesions with more widespread foci of inflammation. Five mice had severe lesions with inflammation and necrosis. No pathology was observed in any of the control mice.

Three out of nine treated nude mice showed no histological sign of inflammation in the brain, while six mice exhibited mild lesions with accumulations of a few inflammatory cells. The lesions and inflammation were found in all six untreated mice. In four mice, a mild inflammation was present, two other mice showed moderate lesions and inflammation. Severe inflammation with widespread necrotic foci were not found in any of these nude mice. No significant lesion was detected in any of the uninfected control animals. 
Fig. 2A-D Histology of Neospora caninum-infected murine $(\mu \mathrm{MT})$ brains, HE staining, 200×. A Uninfected control (-); B mild inflammation with perivascular cuffs $(+)$; $\mathbf{C}$ moderate inflammation $(++)$; D widespread necrosis $(+++)$
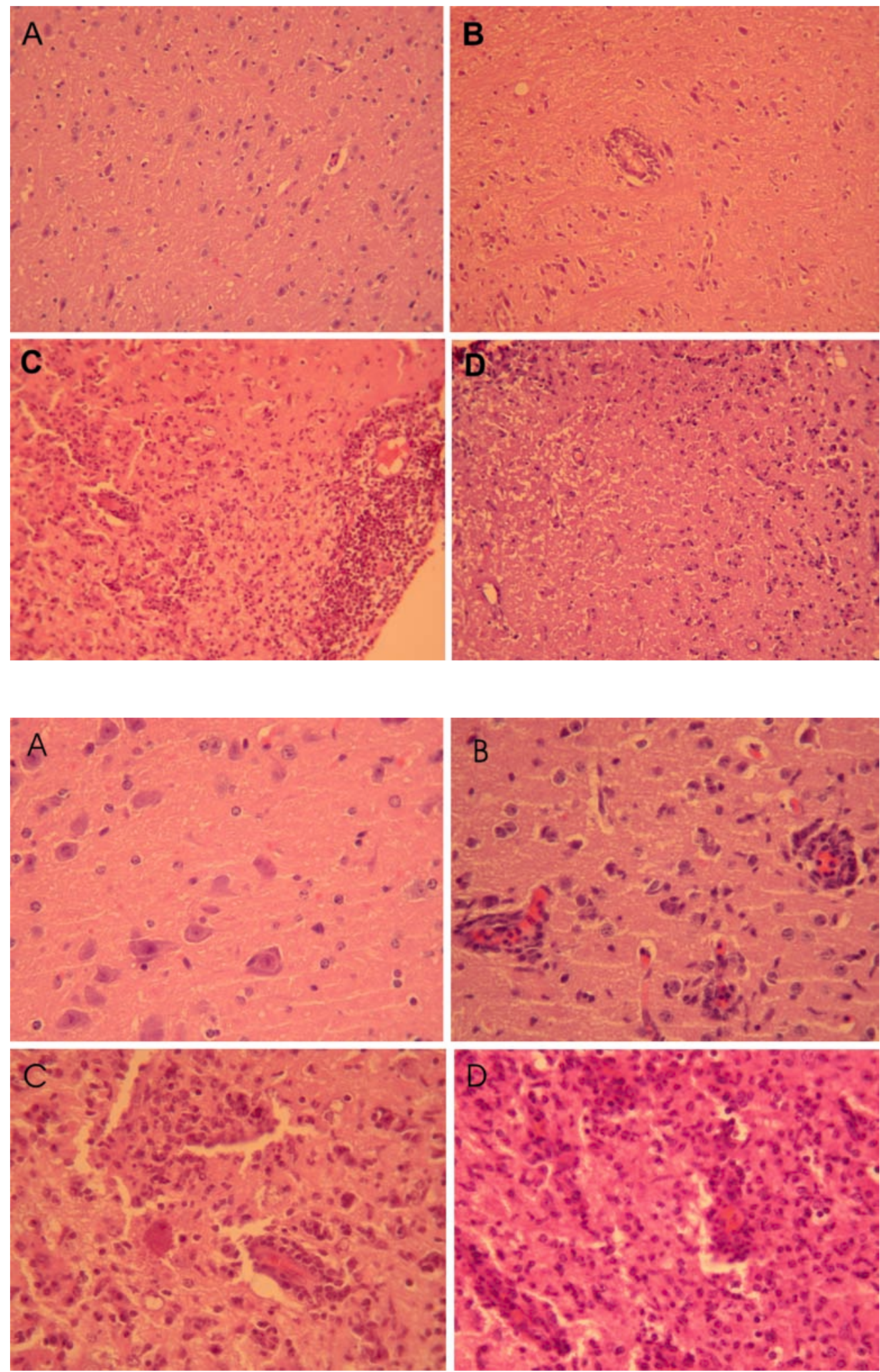

Fig. 3A-D Histology of $N$. caninum-infected murine ( $\mu \mathrm{MT})$ brains, H-E staining, 400×. A Uninfected control (-); B slight inflammation with perivascular cuffs $(+)$; $\mathbf{C}$ moderate inflammation $(++)$; $\mathbf{D}$ severe inflammation $(+++)$
Immunohistochemistry

All sections were immunohistochemically attributed to one of four grades according to the parasite numbers detected, as exemplified in Fig. 4. Parasites were not detected by immunohistochemistry in any of the treated C57BL/6 WT mice or six out of eight treated BALB/c WT mice (Table 5). Single tachyzoites were found in two out of eight $\mathrm{C} 57 \mathrm{BL} / 6 \mathrm{WT}$ mice and three out of eight $\mathrm{BALB} / \mathrm{c}$ mice from the untreated groups. All uninfected control mice were free from parasites. 
Table 4 Assessment of the extent and severity of cerebral lesions related to $N$. caninum infection in $\mathrm{H}-\mathrm{E}$ stained sections from $N$. caninum-infected $\mathrm{C} 57 \mathrm{BL} / 6 \mathrm{WT}$ and $\mathrm{BALB} / \mathrm{C}$ (eight treated versus eight untreated per strain), $\mu \mathrm{MT}$ (eight treated versus seven untreated), and nude (nine treated versus six untreated) mice: $(-)$ no lesions; $(+)$ mild inflammation; $(++)$ moderate inflammation and few small necrotic foci; $(+++)$ severe inflammation and extensive necrosis

\begin{tabular}{lllll}
\hline & - & + & ++ & +++ \\
\hline $\begin{array}{l}\text { C57BL/6 WT mice with toltrazuril } \\
\text { therapy }\end{array}$ & 8 & - & - & - \\
Untreated C57BL/6 WT mice & - & 5 & 3 & - \\
BALB/C WT mice with toltrazuril & 6 & 2 & - & - \\
therapy & 2 & 3 & 3 & - \\
Untreated BALB/C WT mice & 5 & 3 & - & - \\
$\mu$ MT mice with toltrazuril therapy & - & 1 & 1 & 5 \\
Untreated $\mu$ MT mice & 3 & 6 & - & - \\
Nude mice with toltrazuril therapy & - & 4 & 2 & - \\
$\quad \begin{array}{l}\text { Untreated nude mice } \\
\quad\end{array}$ & & &
\end{tabular}

In one treated $\mu \mathrm{MT}$ mouse, a few single tachyzoites were seen with immunohistochemistry, despite the negative PCR results. The other treated mice were all negative; no tachyzoites could be seen. Three of the untreated mice showed the presence of a few tachyzoites in the brain, another three mice had a moderate infection intensity in brain, and in one mouse more than 200 tachyzoites were detected per section. All uninfected control $\mu \mathrm{MT}$ mice yielded negative results.
Table 5 Assessment of the extent and severity of cerebral lesions related to $N$. caninum infection after immunohistochemistry from $N$. caninum-infected treated versus untreated C57BL/6 WT, $\mu \mathrm{MT}$ and nude mice (the same animals as listed in Table 4): (-) no lesions; $(+)$ mild inflammation; $(++)$ moderate inflammation and few small necrotic foci; $(+++)$ severe inflammation and extensive necrosis

\begin{tabular}{lllll}
\hline & - & + & ++ & +++ \\
\hline $\begin{array}{l}\text { C57BL/6 WT mice with } \\
\text { toltrazuril therapy }\end{array}$ & 8 & - & - & - \\
Untreated C57BL/6 WT mice & 6 & 2 & - & - \\
BALB/C WT mice with & 6 & 2 & - & - \\
$\quad \begin{array}{l}\text { toltrazuril therapy } \\
\text { Untreated BALB/C WT mice }\end{array}$ & 5 & 3 & - & - \\
$\mu$ MT mice with toltrazuril therapy & 7 & 1 & - & - \\
$\quad \begin{array}{l}\text { Untreated } \mu \text { MT mice } \\
\text { Nude mice with toltrazuril }\end{array}$ & - & 3 & 3 & 1 \\
$\quad \begin{array}{l}\text { Unerapy } \\
\text { Untreated nude mice }\end{array}$ & 6 & 2 & 1 & - \\
\hline
\end{tabular}

Immunohistochemistry of nude mouse brains revealed the same tendency as found using histology. Three out of nine treated mice had no detectable parasites in the brain. In two mice, just a few parasites were found, and a moderate number of parasites was seen in only one mouse. Conversely, infection became apparent in most of the seven untreated nude mice: in four mice with few and in one mouse with a moderate number of
Fig. 4A-D Immunohistochemical investigation of N. caninum-infected murine $(\mu \mathrm{MT})$ brains, using a polyclonal rabbit anti$N$. caninum hyperimmune serum and an FITC-labelled second antibody; $600 \times$. A Uninfected control (-); $\mathbf{B}$ mild invasion with tachyzoites $(+)$; $\mathbf{C}$ moderate invasion with tachyzoites $(++)$; D severe invasion with tachyzoites $(+++)$
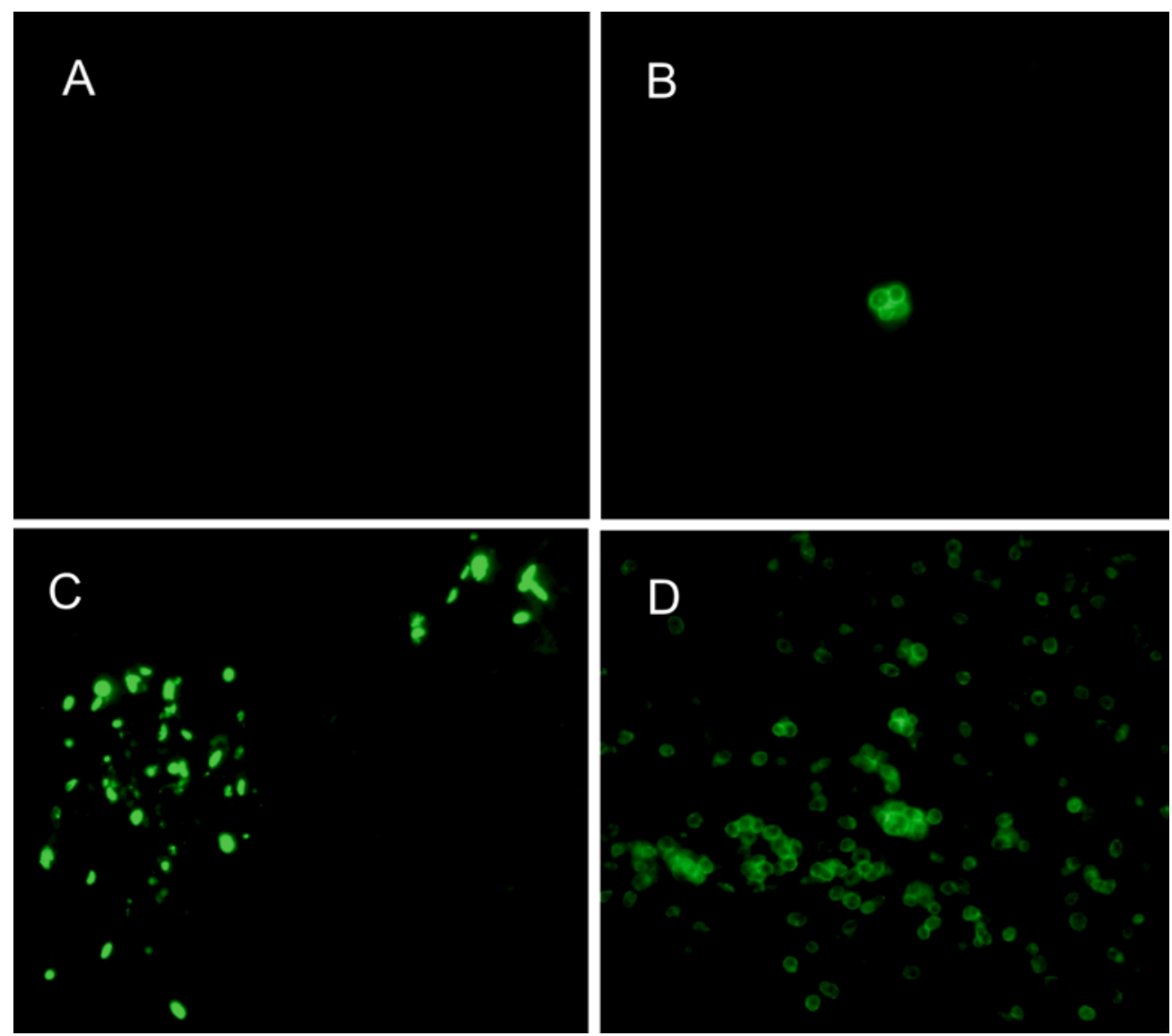
detectable parasites. All uninfected controls were free from parasites.

\section{Discussion}

The results of the present study show that the elimination of the parasite can only be achieved in mice with an intact cell-mediated immune system. Thus, all untreated WT mice became infected but without exhibiting any clinical symptoms. We had expected this, as we had opted for a relatively low infection dose in anticipation of a higher susceptibility to infection in immune compromised mice. Following necropsy, parasite DNA was nevertheless detected by PCR in all of the brains of C57BL/6 WT mice and most of the BALB/c WT mice, but not in the other organs of the infected and untreated mice. Most untreated WT mice had slight to moderate non-suppurative, multifocal encephalitis. Immunohistochemistry did not reveal parasites in all brains with HE-detected lesions, but, conversely, all brains with detectable parasites also had detectable lesions. Methodically, one brain hemisphere was taken for PCR analysis, while the other half served for histological and immunohistochemical investigation. As mentioned previously, the distribution of parasites and associated lesions can vary between different locations in the brain (Gottstein et al. 2001; Sager et al. 2001). This may explain the lack of PCR-amplifiable DNA despite the presence of histological findings in, for example, one untreated WT mouse that was negative by PCR but that had lesions in the brain.

Long et al. (1998) reported that both BALB/c and C57BL $/ 6$ mice exhibited similar high numbers of brain lesions and intracerebral tachyzoites when compared to B10.D2 mice. In our study, infection resulted in a higher parasite load in the brains in $\mathrm{BALB} / \mathrm{c}$ when compared to $\mathrm{C} 57 \mathrm{BL} / 6$ mice, for both untreated and treated animals (as shown by PCR, histology and immunohistochemistry). In treated WT C57BL/6 mice, the parasite did not damage the brain because neither lesions nor parasites were detected upon histological examination, whereas two out of eight treated WT BALB/c mice were not completely cleared by toltrazuril.

Therapy did not affect the parasite before immunocompetent mice mounted an antibody response. This, however, was significantly weaker in treated than in untreated animals. These findings confirmed previous observations (Greif 2000; Gottstein et al. 2001; Kritzner et al. 2002). Toltrazuril does not appear to exhibit an immediate knockdown effect, thus requiring the immune system to become active against the parasite. Nevertheless, the tachyzoites were probably eliminated before having invaded the brain. In untreated animals, the infection was also clinically contained, although brain damage was not completely prevented and a few single tachyzoites were visible by immunofluorescence in one untreated mouse.
One untreated $\mu \mathrm{MT}$ mouse died 26 days p.i.; the rest of the animals showed no clinical signs at the day of necropsy. Similarly, in a previous experiment $\mu$ MT mice infected with $10^{5} \mathrm{Nc}-1$ tachyzoites had started to die after 29 days p.i. (Eperon et al. 1999). N. caninum DNA was detected by PCR in all brains and most of the organs, as also found by Eperon et al. (1999). In infected $\mu \mathrm{MT}$ mice that had received toltrazuril treatment, no $N$. caninum DNA was detected by PCR in any of the organs. As expected, no antibodies to $N$. caninum antigen were detected in any $\mu \mathrm{MT}$ mouse. Consequently, toltrazuril seems to be efficient in reducing the dissemination of tachyzoites even in the absence of antibodies, although a few tachyzoites were also detected by immunohistochemistry in one treated and PCR-negative $\mu \mathrm{MT}$ mouse. This may be related to a topographically uneven distribution of the few remaining parasites. Nevertheless, in seven out of eight treated mice no parasites were found by immunofluorescence, whereas parasites were seen in all of the untreated mice.

In untreated mice, the lack of B-cell immunity was in line with a complete failure to control the infection (Eperon et al. 1999), thus indicating that antibodies may play a crucial role in the control of infection. Following treatment with toltrazuril, $\mu \mathrm{MT}$ mice seemed to be able to control infection up to the point that, despite the presence of some parasites in the brain in a few cases, no widespread inflammation or necrosis was induced. The results obtained with $\mu \mathrm{MT}$ mice demonstrate that toltrazuri -treatment can apparently act in an antibody independent manner. Whether cellular immune mechanisms support the chemotherapeutical effect in clearing the infection is not deducible from these experiments. This question was subsequently addressed with experiments carried out using athymic nude mice.

In previous experiments, we showed that athymic $\mathrm{nu}^{-} / \mathrm{nu}^{-}$mice exhibit a very high susceptibility to infection and disease (Yamage et al. 1996). In the present experiments, the parasite could be found in all organs of most of the untreated mice at day 15 p.i. At this time, the brain of most treated nude mice was still free of parasites (assessed by PCR and immunohistochemistry). Nevertheless, the parasites had not been eliminated, as tachyzoites remained, e.g. detected in most lungs and hearts. Repeating the experiments with a longer time span after treatment tested the parasite survival hypothesis, in that mice stared to die upon day 26 p.i., thus we decided to kill all animals on day 28 p.i. Nevertheless, medicated nude mice survived markedly longer than untreated animals. From these experiments we can conclude that a 6-day toltrazuril treatment has a parasitostatic rather than a parasitocidic effect. Compared to WT or $\mu \mathrm{MT}$ mice, the periparasitic host reaction was significantly lower in nude mice. Thus, only a mild polymorphonuclear inflammation was present. Clusters of parasites were found intracellularly and extracellularly in several mice by LM. Thick-walled cysts were never observed. Toltrazuril is not efficient at preventing 
neosporosis in nude mice. Although it delays the outbreak of disease, it cannot inhibit the spread of tachyzoites. Infection with $10^{6} \mathrm{Nc}-1$ tachyzoites is fatal for athymic nude mice.

The results obtained with athymic $\mathrm{nu}^{-} / \mathrm{nu}^{-}$mice demonstrate conclusively that toltrazuril can not clear the infection, but that its use resulted in a marked delay of parasite dissemination and disease in this T-celldeficient host. T-cells thus seem to play a crucial role in protection against $N$. caninum. Also, interferon- $\gamma$ and interleukin-12 knockout mice exhibited a high susceptibility to acute neosporosis (Khan et al. 1997; Baszler et al. 1999; Nishikawa et al. 2001).

Toltrazuril is effective against experimental infections with $N$. caninum in mice. Experimental infection of susceptible $\mu \mathrm{MT}$ mice indicated that an antibody response is not required to support the effect of medication. Conversely, T-cell immunity is essential to bring the infection under control. An effect of toltrazuril on tachyzoites is demonstrated by the delayed spread of the parasite and the longer survival of treated athymic nude mice. Therefore, we conclude that a parasitostatic effect of toltrazuril occurs that requires the accompaniment of T-cell immunity to evoke its full effect. So far, the application of toltrazuril has not been tested in naturally occurring acute or chronic infections. Future experiments will therefore also have to address the stage specificity of chemotherapy, as well as host specificity.

Acknowledgements This work was supported by the Swiss Federal Veterinary Office (grant no. 1.01.02), BBW grant C01.0122 in the framework of COST 854 ACTION and Bayer Animal Health. We are thankful to Mrs. S. Marty for her assistance in taking care of laboratory animals. Many thanks also to A. Naguleswaran for the $N$. caninum tachyzoite cultivation and A. Hemphill for fruitful discussions.

\section{References}

Anderson ML, Reynolds JP, Rowe JD, Sverlow KW, Packham AE, Barr BC, Conrad PA (1997) Evidence of vertical transmission of Neospora sp. infection in dairy cattle. J Am Vet Med Assoc 210:1169-1172

Andrianarivo AG, Rowe JD, Barr BC, Anderson ML, Packham AE, Sverlow KW, Choromanski L, Loui C, Grace A, Conrad PA (2000) A POLYGEN-adjuvanted killed Neospora caninum tachyzoite preparation failed to prevent foetal infection in pregnant cattle following i.v./i.m. experimental tachyzoite challenge. Int J Parasitol 30:985-990

Baszler TV, Long MT, McElwain TF, Mathison BA (1999) Interferon-gamma and interleukin-12 mediate protection to acute Neospora caninum infection in $\mathrm{BALB} / \mathrm{c}$ mice. Int $\mathbf{J}$ Parasitol 29:1635-1646

Davison HC, Otter A, Trees AJ (1999) Estimation of vertical and horizontal transmission parameters of Neospora caninum infections in dairy cattle. Int J Parasitol 29:1683-1689

Dubey JP (2003) Review of Neospora caninum and neosporosis in animals. Korean J Parasitol 41:1-16

Dubey JP, Hattel AL, Lindsay DS, Topper MJ (1988) Neonatal Neospora caninum infection in dogs: isolation of the causative agent and experimental transmission. J Am Vet Med Assoc 193:1259-1263
Eperon S, Brönnimann K, Hemphill A, Gottstein B (1999) Susceptibility of B-cell deficient C57BL/6 ( $\mu \mathrm{MT}$ ) mice to Neospora caninum infection. Parasite Immunol 21:225-236

Gottstein B, Eperon S, Dai WJ, Cannas A, Hemphill A, Greif G (2001) Efficacy of toltrazuril and ponazuril against experimental Neospora caninum infection in mice. Parasitol Res 87:43-48

Greif G (2000) Immunity to coccidiosis after treatment with toltrazuril. Parasitol Res 86:787-790

Greif G, Harder A, Haberkorn A (2001) Chemotherapeutic approaches to protozoa: Coccidiae - current level of knowledge and outlook. Parasitol Res 87:973-975

Hemphill A, Gottstein B, Kaufmann H (1996) Adhesion and invasion of bovine endothelial cells by Neospora caninum. Parasitology 112:183-197

Innes EA, Buxton D, Eperon S, Gottstein B (2000) Immunology of Neospora caninum infection in cattle and mice. Int $\mathbf{J}$ Parasitol 30:896-900

Innes EA, Andrianarivo AG, Bjorkman C, Williams DJ, Conrad PA (2002) Immune responses to Neospora caninum and prospects for vaccination. Trends Parasitol 18:497-504

Khan IA, Schwartzman JD, Fonseka S, Kasper LH (1997) Neospora caninum: role for immune cytokines in host immunity. Exp Parasitol 85:24-34

Kim JT, Park JY, Seo HS, Oh HG, Noh JW, Kim JH, Kim DY, Youn HJ (2002) In vitro antiprotozoal effects of artemisinin on Neospora caninum. Vet Parasitol 103:53-63

Kritzner S, Sager H, Blum J, Krebber R, Greif G, Gottstein B (2002) An explorative study to assess the efficacy of toltrazurilsulfone (Ponazuril) in calves experimentally infected with Neospora caninum. Ann Clin Microbiol Antimicrob 1:4

Kwon HJ, Kim JH, Kim M, Lee JK, Hwang WS, Kim DY (2003) Anti-parasitic activity of depudecin on Neospora caninum via the inhibition of histone deacetylase. Vet Parasitol 112:269-276

Liddell S, Jenkins MC, Collica CM, Dubey JP (1999) Prevention of vertical transfer of Neospora caninum in BALB/c mice by vaccination. J Parasitol 85:1072-1075

Lindsay DS, Dubey JP (1990a) Infections in mice with tachyzoites and bradyzoites of Neospora caninum (Protozoa: Apicomplexa). J Parasitol 76:410-413

Lindsay DS, Dubey JP (1990b) Effects of sulfadiazine and amprolium on Neospora caninum (Protozoa: Apicomplexa) infections in mice. J Parasitol 76:177-179

Lindsay DS, Rippey NS, Cole RA, Parsons LC, Dubey JP, Tidwell RR, Blagburn BL (1994) Examination of the activities of 43 chemotherapeutic agents against Neospora caninum tachyzoites in cultured cells. Am J Vet Res 55:976-981

Lindsay DS, Lenz SD, Cole RA, Dubey JP, Blagburn BL (1995) Mouse model for central nervous system Neospora caninum infections. J Parasitol 81:313-315

Long MT, Baszler TV, Mathison BA (1998) Comparison of intracerebral parasite load, lesion development, and systemic cytokines in mouse strains infected with Neospora caninum. J Parasitol 84:316-320

Müller N, Zimmermann V, Hentrich B, Gottstein B (1996) Diagnosis of Neospora caninum and Toxoplasma gondii infection by PCR and DNA hybridization immunoassay. J Clin Microbiol 34:2850-2852

Nishikawa Y, Inoue N, Xuan X, Nagasawa H, Igarashi I, Fujisaki K, Otsuka H, Mikami T (2001) Protective efficacy of vaccination by recombinant vaccinia virus against Neospora caninum infection. Vaccine 19:1381-1390

Ritter DM, Kerlin R, Sibert G, Brake D (2002) Immune factors influencing the course of infection with Neospora caninum in the murine host. J Parasitol 88:271-280

Sager H, Fischer I, Furrer K, Strasser M, Waldvogel A, Boerlin P, Audigé L, Gottstein B (2001) A Swiss case-control study to assess Neospora caninum-associated bovine abortions by PCR, histopathology and serology. Vet Parasitol 102:1-15

Schares G, Peters M, Wurm R, Bärwald A, Conraths FJ (1998) The efficiency of vertical transmission of Neospora caninum in dairy cattle analysed by serological techniques. Vet Parasitol 80:8798 
Shibahara T, Kokuho T, Eto M, Haritani M, Hamaoka T, Shimura K, Nakamura K, Yokomizo Y, Yamane I (1999) Pathological and immunological findings of athymic nude and congenic wild type BALB/c mice experimentally infected with Neospora caninum. Vet Pathol 36:321-327
Yamage M, Flechtner O, Gottstein B (1996) Neospora caninum: specific oligonucleotide primers for the detection of brain "cyst" DNA of experimentally infected nude mice by the polymerase chain reaction (PCR). J Parasitol 82:272-279 